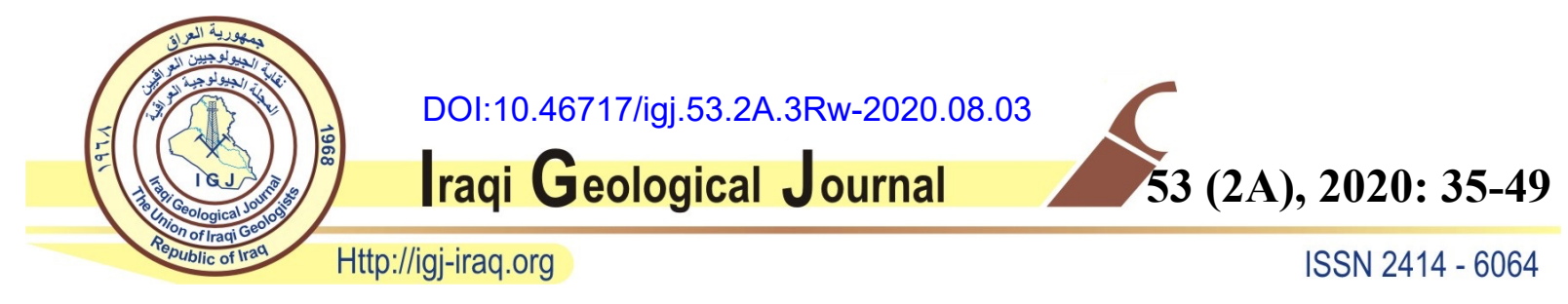

\title{
APPLICATION OF TRIANGLES METHOD FOR QUANTITATIVE ESTIMATION OF MARL RESERVE IN EUPHRATES FORMATION, MIDDLE OF IRAQ
}

\author{
${ }^{1}$ Salih Muhammad Awadh* and ${ }^{2}$ Mohanad R. A. Al-Owaidi \\ ${ }^{1}$ Department of Geology, College of Science, University of Baghdad, Baghdad, Iraq \\ ${ }^{2}$ Department of Applied Geology, College of Science, University of Babylon, Babylon, Iraq \\ *E-mail: salihauad2000@yahoo.com \\ Received: 19 April 2020; accepted: 29 May 2020
}

\begin{abstract}
The Raw materials are of great importance for producing a high-quality Portland Cement. Calcium, silica, and alumina are essential components of the initial mixture used for the manufacture of the Portland Cement. The marl bed in the Euphrates Formation at the quarries of the Kufa cement plant was proposed to be an alternative raw material to provide such components to the cement mixture. For this reason, nine boreholes were drilled in addition to three boreholes that had been previously drilled in the study area. The marl reserve was classified according to the Russian classification as a C1 category, and as a probable reserve according to the British classification and estimated as a reserve of 53 million tons by using the triangle method. Porosity (30.47\%), Bulk density $\left(1.73 \mathrm{gm} / \mathrm{cm}^{3}\right.$ ) and compressive strength $\left(3.59 \mathrm{~N} / \mathrm{m}^{2}\right)$ were measured and show the homogeneity of hardness can serve in the reduction of the electrical energy consumption and the wear of equipment productivity and increase the production of the mills, that are reflected eventually in the reduction of the final product cost.
\end{abstract}

Keywords: Marl; Portland Cement; Reserve estimation; Triangle method

\section{INTRODUCTION}

Cement raw materials should be available in sufficient quantities to justify the large capital investments (Ertek and Oner, 2008). A new reserve is therefore must be explored. This research deals economically with marl quantity suitable to be a part of the cement mixture, as the marl reserve was calculated by using the triangle method. There have been previous attempts targeting clays in the construction industry, in particular cement and brick; for example, the Late Miocene clay from Injana Formation in the middle of Iraq was evaluated for manufacturing the Portland cement and bricks as it had been investigated as a raw material alternative to the recent clays that are typically considered as agricultural lands (Awad and Awadh, 2020). The 
British and Russian systems that are used widely for the reserve estimation are currently applied and discussed. Categories of reserve estimation based on the degree of assurance and economic consideration are also classified. The marl in the Euphrates Formation was targeted to be explored as a raw material for the cement industry in Bahr Al-Najaf, a study area (Fig. 1) which is tectonically located within the Salman Subzone, a part of the Stable Shelf Zone. In term of geochemistry, the Euphrates Formation in the selected area at Bahr Al-Najaf is qualified as it has lithofacies suitable to be raw materials valid for manufacturing the Portland cement (AlDabbas et al., 2013). The aim of the current research is to determine the specification of the marl bed in the Euphrates Formation and estimate its reserve by tonnage that in corresponding to the specifications of Portland cement production using the triangle method.

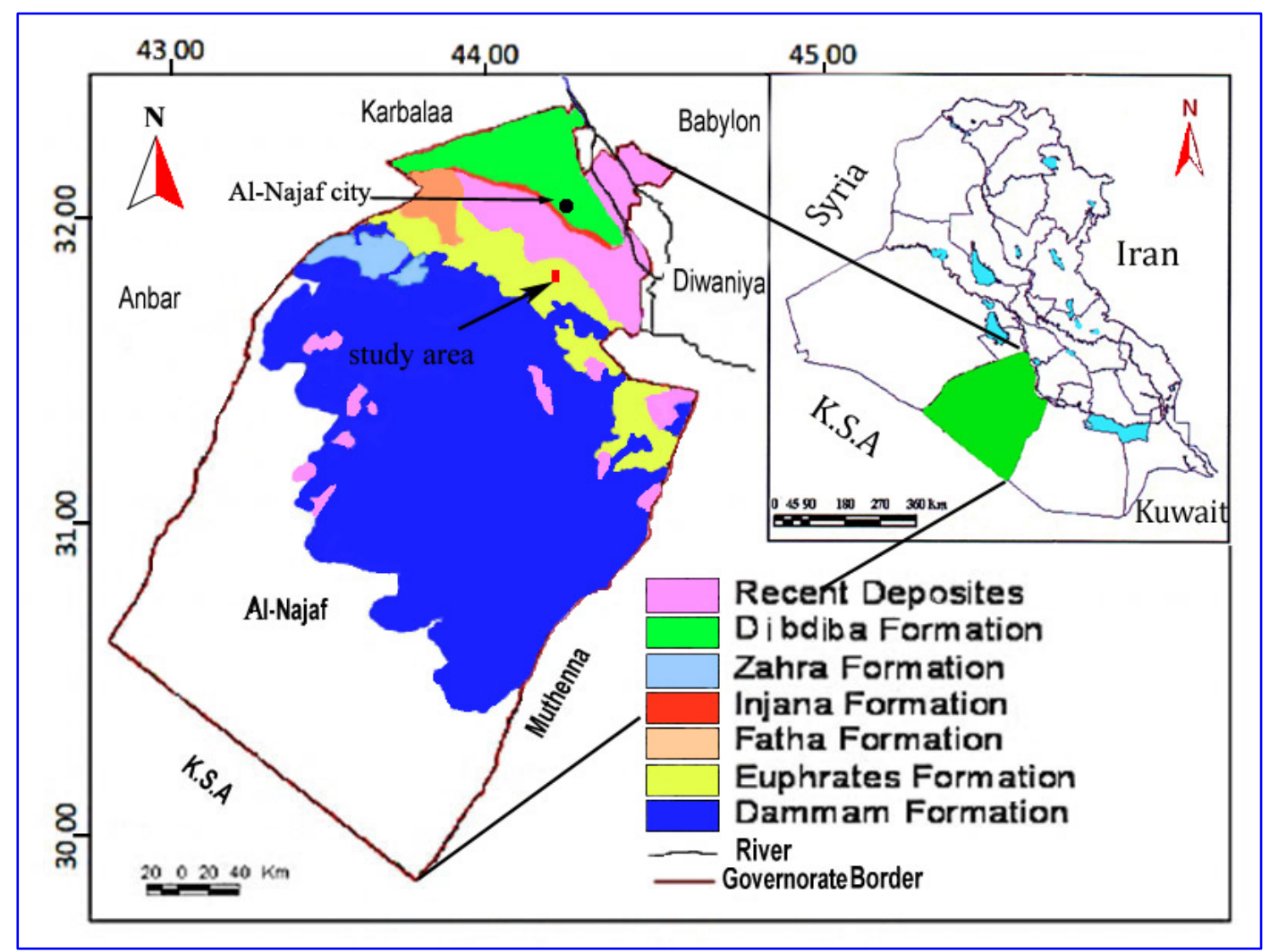

Fig. 1. Geological map of the study area (Sissakian, 2000)

\section{GEOLOGICAL SETTING}

The Euphrates formation (Lower Miocene) is deposited in a shallow environment (Jassim and Goff, 2006) composing of dolomitic, fossiliferous, and oolitic limestones with green marls at the top (Al-Dabbas et al., 2014). It is exposed to the surface in most, and somewhere being hidden subsurface. The stratigraphy of the study area is described from the oldest as Dammam, Euphrates, Nfayil, Injana, Zahra, Dibdibba, and the Quaternary deposits (Awadh et al., 2013). During the Late Miocene, the Mesopotamian basin was very shallow and relatively littoral at the beginning clastic and calcareous like the Euphrates Formation. In the Middle Miocene, the 
basin was developed as it had been during the Lower Miocene, where calcareous (Nfayil Formation) was deposited in shallow water (Buday, 1980). In the Upper Miocene-Pliocene, uplift on the whole Stable Shelf had been happened (Awadh and Al-Ankaz, 2016). Accordingly, the paleogeographic was influenced and marked by the deposition of terrigenous syn and postorogenic clastic molasses in the subsiding and mobile foredeep (Injana Formation). Later, at the Quaternary, the river systems had been acted and developed (Buday and Jassim, 1987). The depth of the marl layer emplaced within the Euphrates Formation is just $3 \mathrm{~m}$ with a thickness of about $8 \mathrm{~m}$ interbedded with marly limestone $(0.5 \mathrm{~m}$ thick) covered by limestone overburden. The stratigraphic section of the Euphrates Formation is illustrated in Fig 2.

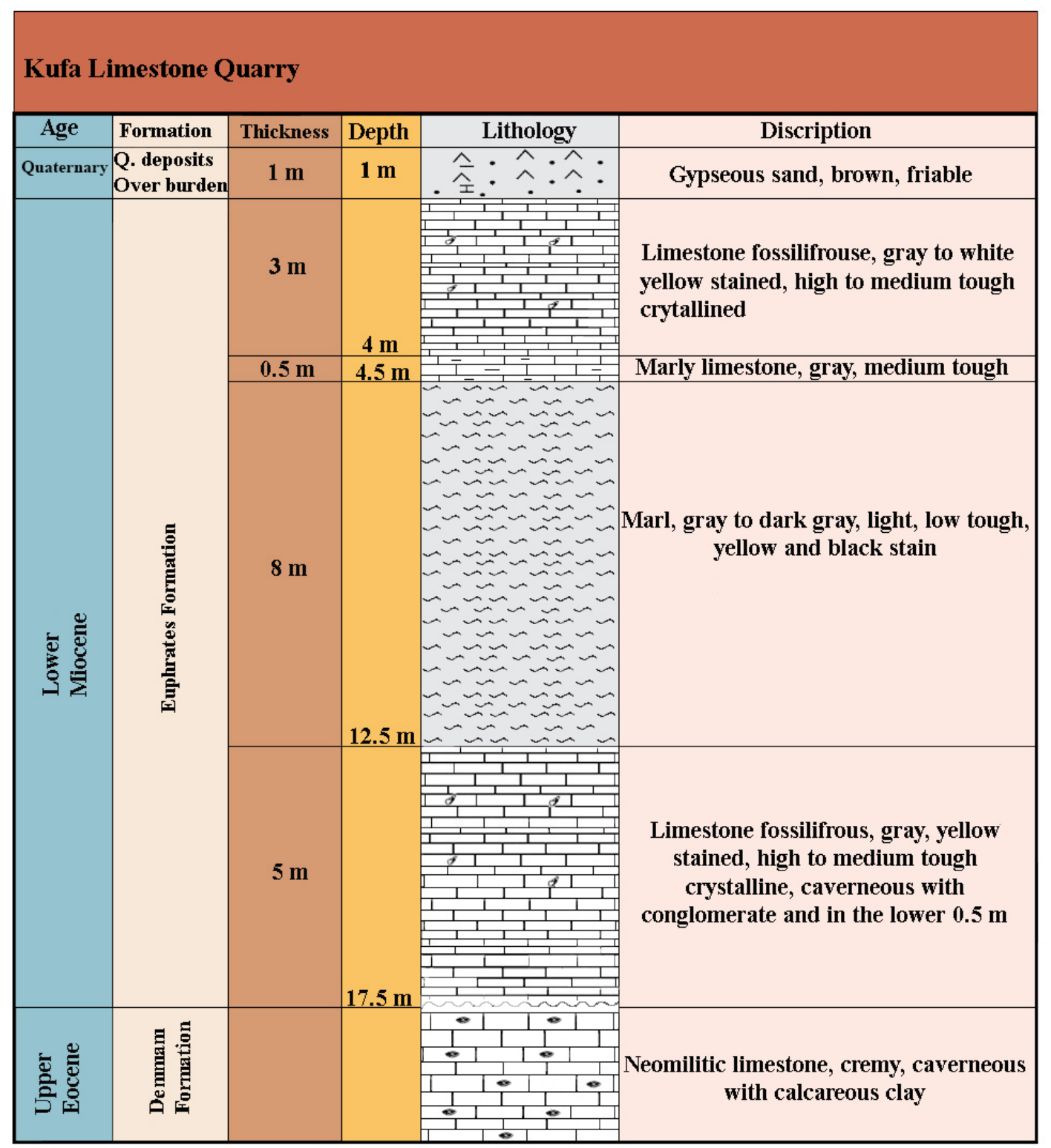

Fig. 2. Stratigraphic section of the Euphrates Formation in the study area 


\section{MATERIALS AND METHODS}

A total of nine wells (X1, X2, X3, Y1, Y2, Y3, Z1, Z2 and Z3) in the study area were drilled by the Nordmeyer drill machine with a diameter $102 \mathrm{~mm}$ and heavy-duty excavator (Komatsu PC600) to depth ranges 8-15 m. They are compared to three wells (BH.1, BH.2, and BH.3) that have been previously drilled by the Danish Geotechnical Institute in 1976 during the period of opening the quarry of the Kufa Cement Plant. The thickness of the economic layer, the grade of the deposit, bulk density, porosity and volume in the study area are controlling the reserve (Wellmer et al., 2008) The area of interest was horizontally; and vertically sampled and the thickness and total area, were calculated and later the isopach map was drawn by surfer program. Six samples were systematically selected for determining porosity, bulk density, and uniaxial compressive strength as the main part of the physical tests.

\section{RESERVE ESTIMATION OVERVIEW}

The marl is a part of the raw materials required for the cement industry. This raw material was known by drilling and specific measurement and has been shown it can be economically extracted and tonnage estimated. The systems of reserve that are used are: British System, a system was introduced by the British Institution of Mining and Metallurgy in 1902 by which the reserve is divided into three types (proved, probable and possible). The Proved reserve is the estimation based on sufficient data that does not vary much from the actual tonnage and grade and; characterized by a high probability degree of geological assurance up to $80 \%$.

The probable reserve is defined as that estimation of a lesser degree of assurance and based on limited data on sampling and core logging with geological assurance up to $50 \%$. The possible reserve is that reserve estimated from exploring the sampling data in the area, from which no data of sampling is available with geological assurance not exceed 15\%. Russian System is dividing the reserve into four main categories (A, B, C1 and C2). These categories are seen as commercial; whose extraction is economically viable. The (A, B and $\mathrm{C} 1)$ reserves are industrial and C2 is geological (Kreiter, 1968). The A category determines the reserves in place in detail and outlines the boundaries of the deposit by trenching, drilling, or underground workings with allowable error ranges from 15 to $20 \%$ (Kreiter, 1968). It is equivalent to the proven system in the British System (Table 1). The B category reserve is explored the reserve but only in fair detail. So, it is equivalent to the proved-probable class in the British System (Table 1). It is used for estimating mining investment and for planning the development of the deposit with permissible error ranges from 20 to 30\%. The reserves in $\mathrm{C} 1$ class are used for the long term development plans of industry and for projecting detailed exploration and equivalent 
to the probable class in the British System (Table 1), with permissible error varies from 30 to $60 \%$ (Kreiter, 1968). The Class C2 reserve is based on an extremely loose exploration grid, with poor data. This category of Russian classification represents the estimates obtained from a small exploratory data by a large-scale interval of sampling. This category is equivalent to a possible class in the British System (Henley, 2004) with an error of 60-90\% (Kreiter, 1968).

Table 1. Relationship of the reserve classification systems with each other

\begin{tabular}{|c|c|c|c|c|c|}
\hline British System & Possible & \multicolumn{2}{|c|}{ Probable } & \multicolumn{2}{|c|}{ Proved } \\
\hline Russian System & C2 & C1 & B & A \\
\hline
\end{tabular}

\section{RESULTS AND DISCUSSION}

The reserve tonnage of marl layer has been estimated:

\section{The Marl Volume}

Marl layer in the Euphrates Formation is exposed to the surface in sites from which limestone had been extracted. Marl layer is of horizontal continuous extension underlying limestone detected in boreholes BH.1, BH.2 and BH.3 at distance $6.128,4.506$ and $4.522 \mathrm{~km}$, respectively from the borehole (X1) with average thickness $6.5 \mathrm{~m}$ (Fig. 3).

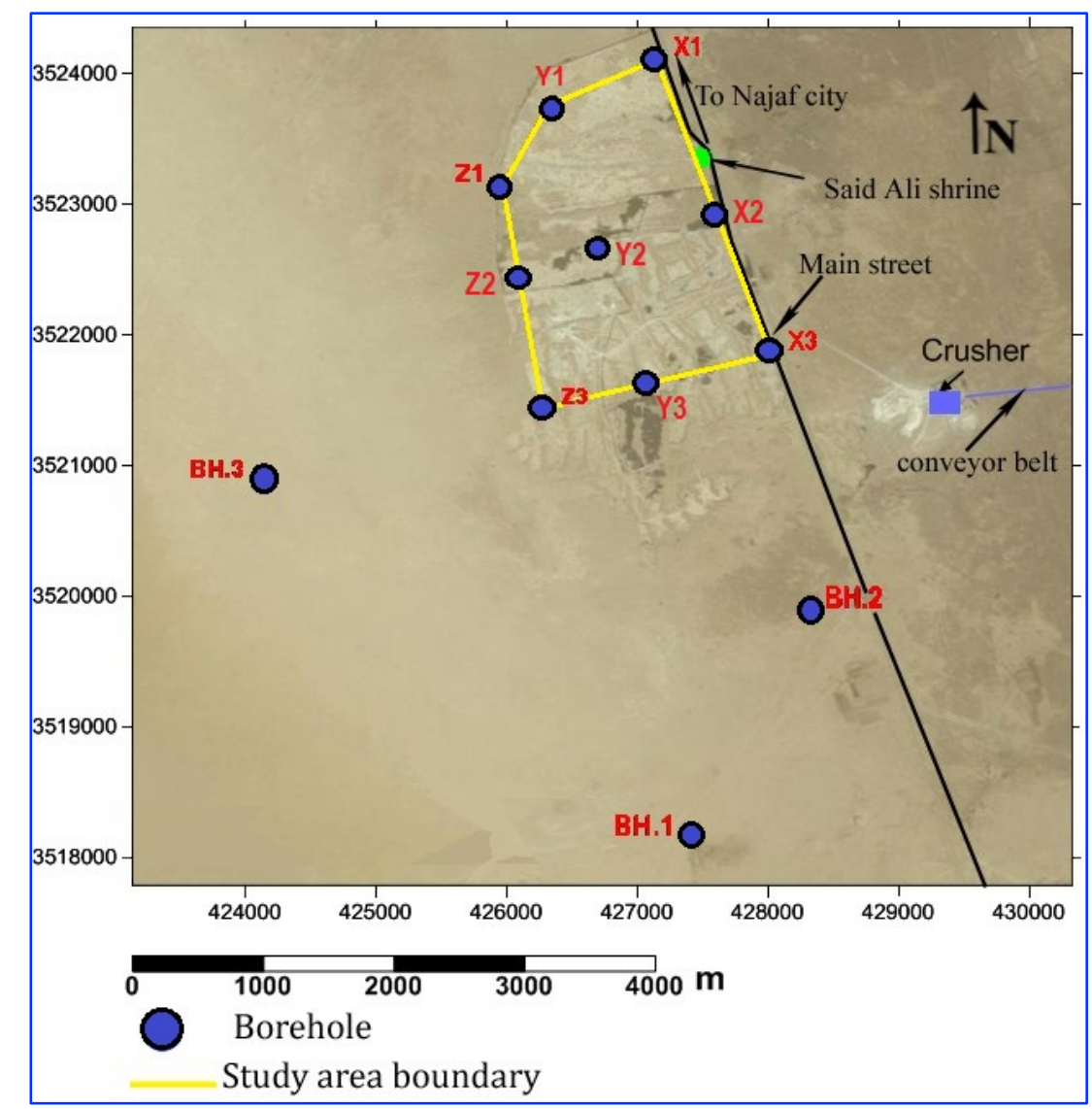

Fig. 3. Land sat image of the study area in which three boreholes confirm the presence of the marl layer beneath the limestone layer 
A quantitative assessment has been carried out by which reserve is estimated by tonnage for the significant grade involving three parameters: grade, volume and bulk density (Lipton, 2011). The calculation of reserve estimation of the marl layer depends on data collected from nine wells. The thickness of marl the layer and physical tests (bulk density, compressive strength, and apparent porosity) are control factors of the possibility of the reserve utilizing for industrial purposes. The thickness of the marl layer called also industrial layer was computed by the information obtained from the drilled borehole to be ranged from $7.75 \mathrm{~m}$ in the borehole $\mathrm{Z} 2$ to $9 \mathrm{~m}$ in the borehole X1 with an average of $8 \mathrm{~m}$ (Table 2) and (Fig. 4). The marl layer continues to boreholes BH.1, BH.2, and BH.3 in the south and southeast of the study area with a thickness of $6.5-7 \mathrm{~m}$ covered by limestone and overburden.

Table 2. Location and average thickness of the marl layer

\begin{tabular}{|c|c|c|c|c|}
\hline \multirow{2}{*}{$\begin{array}{c}\text { Borehole } \\
\text { No. }\end{array}$} & \multicolumn{2}{|c|}{ UTM-Coordination } & \multirow{2}{*}{$\begin{array}{c}\text { Marl layer } \\
\text { Thickness (m) }\end{array}$} & \multirow{2}{*}{$\begin{array}{c}\text { Elevation } \\
\text { (m) }\end{array}$} \\
\hline & Easting & Northing & & \\
\hline $\mathrm{X} 1$ & 427122.7 & 3524181.7 & 9.00 & 32 \\
\hline $\mathrm{X} 2$ & 427637.6 & 3522915.6 & 8.70 & 33 \\
\hline $\mathrm{X} 3$ & 428062.3 & 3521863.2 & 8.50 & 34 \\
\hline Y1 & 426282.1 & 3523630.0 & 8.75 & 36 \\
\hline Y2 & 426683.1 & 3522616.9 & 8.50 & 37 \\
\hline Y3 & 427104.4 & 3521636.9 & 8.40 & 38 \\
\hline $\mathrm{Z1}$ & 425947.6 & 3523163.2 & 8.75 & 38 \\
\hline $\mathrm{Z} 2$ & 426026.8 & 3522402.3 & 7.75 & 40 \\
\hline $\mathrm{Z3}$ & 426305.1 & 3521444.6 & 7.80 & 41 \\
\hline BH. 1 & 427516.5 & 3518093.6 & 6.50 & 42 \\
\hline BH. 2 & 428405.9 & 3519899.8 & 6.50 & 38 \\
\hline BH. 3 & 424122.2 & 3520823.4 & 7.0 & 45 \\
\hline
\end{tabular}

\section{Physical Tests}

Dry bulk density, uniaxial compressive strength, and apparent porosity, the most important parameters required for the rock mechanical studies in mining projects were determined (Table 3). The uniaxial compressive strength with apparent porosity is used to estimate the reserve tonnage by testing six samples. Density is an important rock characteristic used to transform measured volumes into tonnages; whereas, porosity is a measure of the volume of voids in material or mass (Price, 2009). The compressive strength is the capacity of a material or structure to withstand loads tending to reduce size. It is measured by plotting applied force against deformation in a testing machine. 


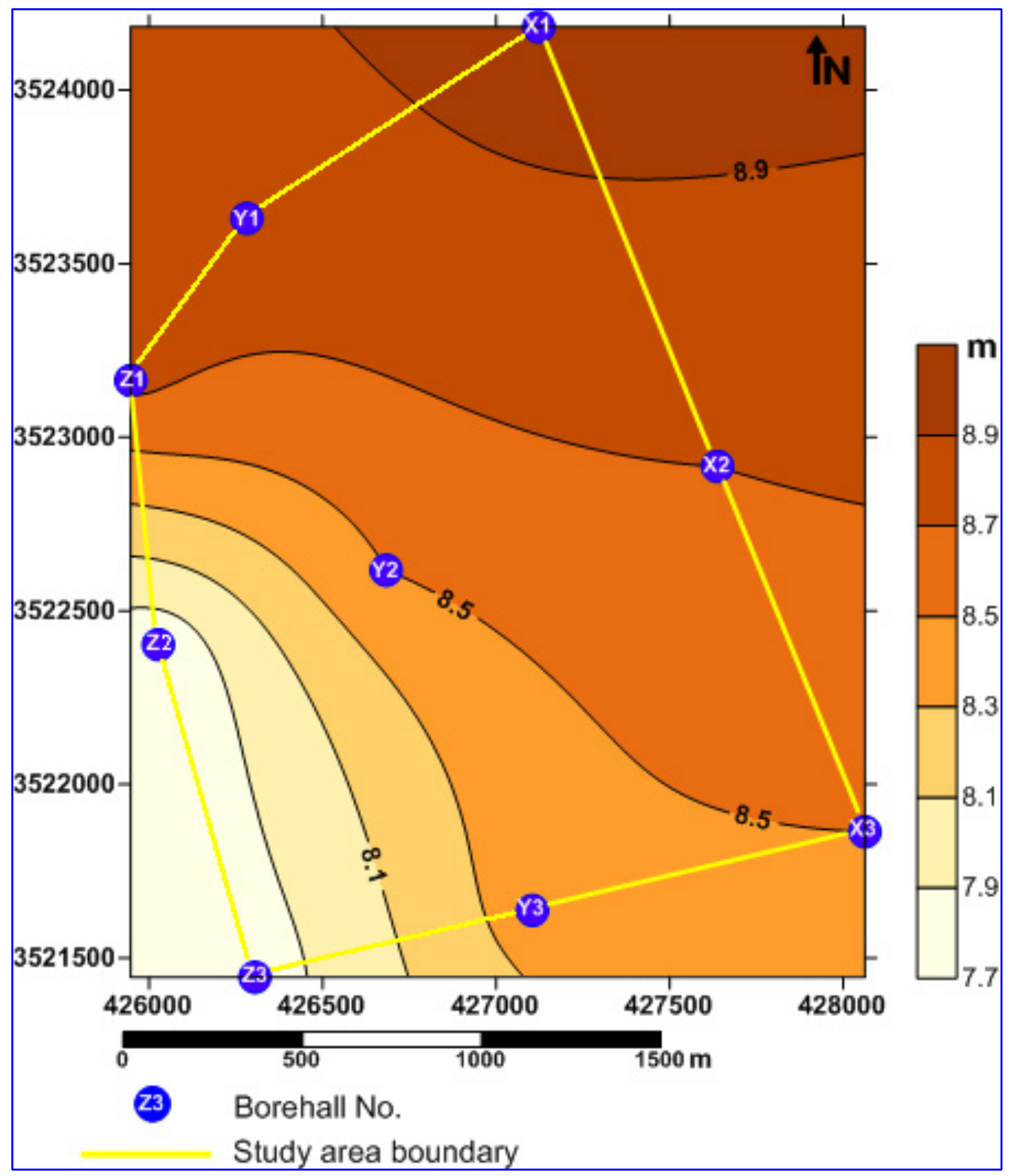

Fig. 4. Isopach map of the marl layer in the study area

Table 3. Results of the physical tests of selected samples

\begin{tabular}{|c|c|c|c|c|c|c|c|c|}
\hline \multirow{2}{*}{$\begin{array}{l}\text { BH. } \\
\text { No. }\end{array}$} & \multirow{2}{*}{$\begin{array}{c}\text { Sample } \\
\text { No. }\end{array}$} & \multicolumn{2}{|c|}{ Interval depth (m) } & \multirow{2}{*}{$\begin{array}{c}\text { Core length } \\
\text { (m) }\end{array}$} & \multirow{2}{*}{$\begin{array}{l}\text { Well depth } \\
\text { (m) }\end{array}$} & \multirow{2}{*}{$\begin{array}{c}\text { Porosity } \\
\text { (\%) }\end{array}$} & \multirow{2}{*}{$\begin{array}{c}{ }^{1} \text { B.D } \\
\left(\mathrm{g} / \mathrm{cm}^{3}\right)\end{array}$} & \multirow{2}{*}{$\begin{array}{c}{ }^{2} \text { C.S (Mega } \\
\left.\text { N } / \mathrm{m}^{2}\right)\end{array}$} \\
\hline & & From & To & & & & & \\
\hline $\mathrm{X} 1$ & 1 & 0.00 & 0.50 & 0.05 & 9.00 & 19.462 & 2.069 & 8.756 \\
\hline $\mathrm{X} 3$ & 2 & 4.00 & 6.00 & 0.05 & 8.50 & 37.025 & 1.659 & 2.037 \\
\hline $\mathrm{Y} 2$ & 3 & 6.00 & 8.00 & 0.05 & 8.75 & 34.092 & 1.644 & 1.968 \\
\hline $\mathrm{Y3}$ & 4 & 2.00 & 4.00 & 0.05 & 8.50 & 36.132 & 1.659 & 2.018 \\
\hline $\mathrm{Z1}$ & 5 & 0.5 & 2.0 & 0.05 & 8.75 & 21.016 & 2.01 & 4.776 \\
\hline $\mathrm{Z3}$ & 6 & 8.00 & 9.00 & 0.05 & 7.80 & 35.092 & 1.644 & 1.984 \\
\hline Av. & & & & & & 30.47 & 1.735 & 3.59 \\
\hline
\end{tabular}

${ }^{1}$ B.D: Bulk density $\left(\mathrm{g} / \mathrm{cm}^{3}\right)$.

${ }^{2}$ C.S: Compressive strength (Mega $\mathrm{N} / \mathrm{m}^{2}$ ). 
The density of the marl layer in the wells of the study area ranges from 1.659 to 2.069 $\mathrm{g} / \mathrm{cm}^{3}$ (average of $1.735 \mathrm{~g} / \mathrm{cm}^{3}$ ), whereas porosity ranging varies from 19.462 to $37.025 \%$, and compressive strength varies from 8.756 (first $0.5 \mathrm{~m}$ ) to $1.968 \mathrm{Mega} \mathrm{N} / \mathrm{m}^{2}$ with an average of 3.59 Mega N/m². The rock hardness is divided into two levels (Chatterjee, 1979) (Table 4) based on the physical tests. The study marl layer was divided into two horizons based on the hardness of Hoek et al. (1998) and Brown (1981) as follows:

a. Weak or medium tough rocks: this horizon, which extends from the exposed surface to $0.5 \mathrm{~m}$, is recognized with bulk density $2.069 \mathrm{~g} / \mathrm{cm}^{3}$, porosity is $19.462 \%$ and uniaxial compressive strength value is less than $8.8 \mathrm{mega} / \mathrm{m}^{2}$. This horizon has a grade of $\mathrm{R} 2$ and forms almost a half meter of the surface of the study area.

Table 4. Marl layer classification based on hardness value

\begin{tabular}{|c|c|c|c|c|c|}
\hline${ }^{1}$ Level & ${ }^{1}$ Grade & $\begin{array}{c}{ }^{2} \mathrm{C.S} \\
\left(\mathrm{mega} \mathrm{N} / \mathrm{m}^{2}\right)\end{array}$ & $\begin{array}{c}{ }^{1} \text { Hardness } \\
\text { type }\end{array}$ & $\begin{array}{l}{ }^{2} \text { Hardness } \\
\text { description }\end{array}$ & $\begin{array}{c}{ }^{3} \text { Excavation } \\
\text { characteristic }\end{array}$ \\
\hline \multirow{6}{*}{$\begin{array}{l}\text { The } \\
\text { first }\end{array}$} & R0 & $0.25-1$ & Very Friable & Extremely weak & \multirow{2}{*}{ Ripping } \\
\hline & $\mathrm{R} 1$ & $>1-5 *$ & Friable * & Very weak * & \\
\hline & $\mathrm{R} 2$ & $>5-25$ & \multirow{2}{*}{$\begin{array}{l}\text { Medium } \\
\text { tough }\end{array}$} & Weak & Hard ripping \\
\hline & R3 & $>25-50$ & & Medium-strong & Very hard ripping \\
\hline & $\mathrm{R} 4$ & $>50-100$ & \multirow{2}{*}{ Tough } & Strong & \multirow{3}{*}{ Blasting } \\
\hline & R5 & $>100-250$ & & Very Strong & \\
\hline $\begin{array}{l}\text { The } \\
\text { second }\end{array}$ & R6 & $>250$ & Very tough & $\begin{array}{l}\text { Extremely } \\
\text { Strong }\end{array}$ & \\
\hline
\end{tabular}

${ }^{1}$ Brown (1981); ${ }^{2}$ Hoek et al. (1998); ${ }^{3}$ Chatterjee (1979).

*The study area

b. Very weak or friable rocks: This horizon is, below the first $0.5 \mathrm{~m}$, recognized by bulk density ranges from 1.644 to $2.01 \mathrm{~g} / \mathrm{cm}^{3}$ with an average of $1.7156 \mathrm{~g} / \mathrm{cm}^{3}$, porosity varies between 21.06 and $37.052 \%$, and the uniaxial compressive strength value ranges from 4.776 to 1.984 mega $\mathrm{N} / \mathrm{m}^{2}$, (average of $2.002 \mathrm{mega} \mathrm{N} / \mathrm{m}^{2}$ ). This horizon is classified as grade R1 (Table 4). The marl layer generally is very weak and ripping which means easily extracted. The costs of mining, crushing, and milling are greatly affected by rock hardness. These items affect both the number and size of the equipment needed and the energy usage and the cost of the consumables needed. Porosity has a major influence on bulk density. Porosity and bulk density are inversely related. The relationship between density and compressibility is positive due to the highdensity evidence of the lack of pores and increase material within the unit volume leading to increase the resistance of the sample to compression. 


\section{Tonnage Estimation by Triangles Method}

Reserve estimation reveals the economic effectiveness of the exploration and provides the data needed to assess the quality of the exploration geologist's work (Kreiter, 1968). The study area is a quadrate shape with dimensions $1.8 \times 2.5 \mathrm{~km}$. For the estimation of the reserve of the marl layer; the study area was divided into nine triangles. Each triangle links three adjacent boreholes (Fig. 5). Because of the triangles are equilateral, and its angle degree unequal $60^{\circ}$, the correction factor is used to correct the marl layer thickness in each triangle depending on Al-Atia (2001) and Wellmer et al., (2008) as follows:

Correction factor (C.F.) $=\frac{\text { angle of the triangle peak }}{60}$

The reserve was calculated by the equation:

$R=A \times A C T \times B . D$

Where:

R: The reserve (ton), A: The triangle area $\left(\mathrm{m}^{2}\right)$, ACT: Average of a corrected thickness (m) and B.D: Average of bulk density $\left(\mathrm{g} / \mathrm{cm}^{3}\right)$

The average corrected thickness of each triangle in the study area calculated by the following equation:

$$
\mathrm{ACT}=\frac{\left(t_{1} \times C f_{1}\right)+\left(t_{2} \times C f_{2}\right)+\left(t_{3} \times C f_{3}\right)}{n}
$$

Where:

$t_{1}, t_{2}$, and $t_{3}$ : Thickness of the marl layer in wells (X3, Y2, and Y3) respectively. $C f_{1}, C f_{2}$ and $C f_{3}$ : Correction factors for each triangle, n: Number of wells.

The area of the triangle is in a unit of $\mathrm{m}^{2}$, according to the equation below (Fig.5):

$$
A=1 / 2 B \times H
$$

Where:

$A$ : The area of the triangle, $B$ : Base and $H$ : Height of triangle

The total Area $\left(\sum\right.$ triangles area $\left.\left(\mathrm{m}^{2}\right)\right)=3639350 \mathrm{~m}^{2}$

The results of reserve calculations depended on the triangle method are listed in (Table 5).

The average bulk density in the study area $=1.735\left(\mathrm{~g} / \mathrm{cm}^{3}\right)$ (Table 4$)$.

The total reserve (R.) $=\sum$ reserve in each the triangle

The total reserve (tonnage) by this method is 53642838 tons. 


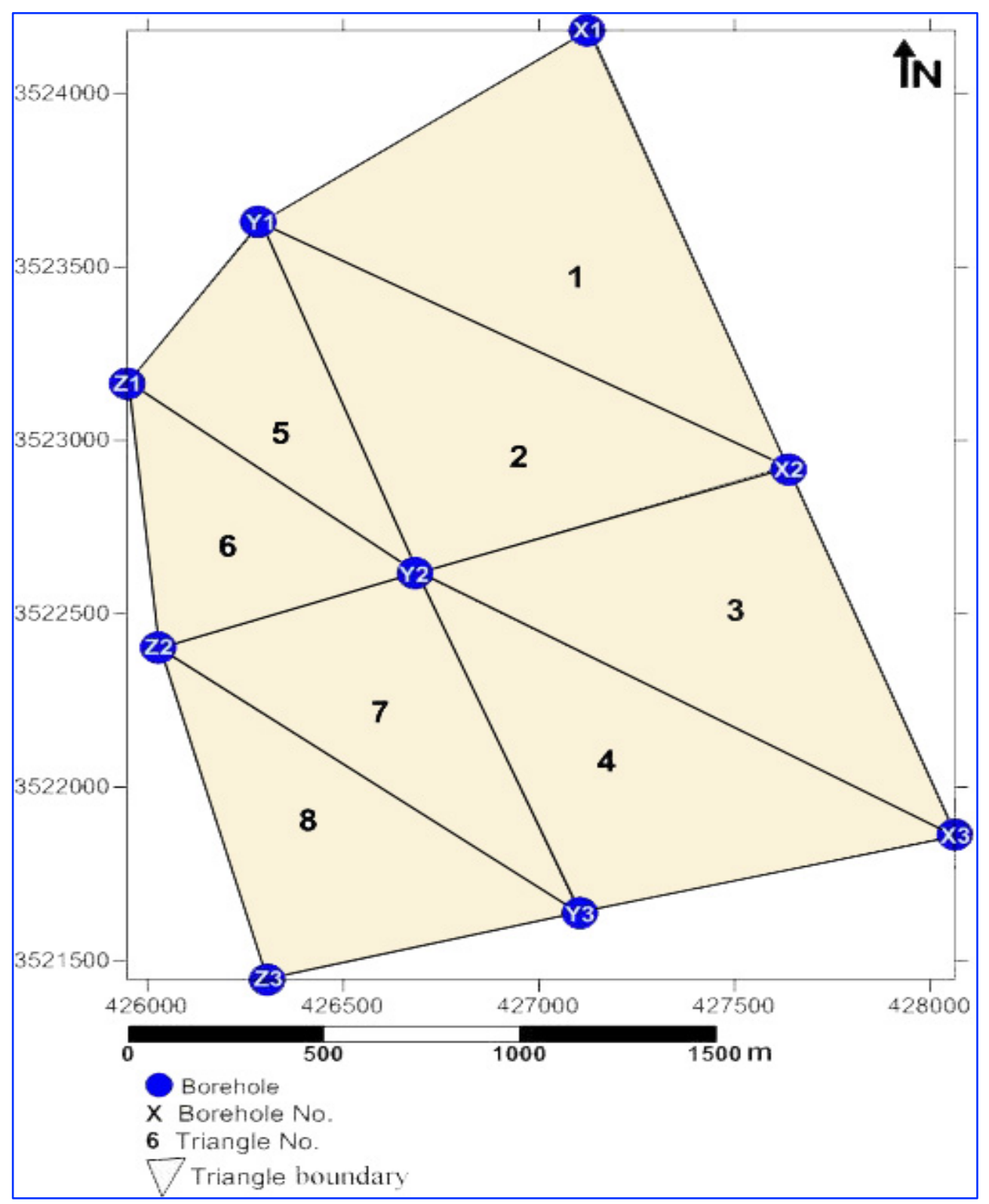

Fig. 5. Plan map of the study area illustrates the triangular blocks link the boreholes

\section{Qualitative Evaluation and Mining}

For opening a new quarry, the distribution and variation of the chemical components must be determined. The first step, in conjunction with the planning of the work in the quarries, is to determine the average chemical composition. The second step is to calculate the raw mix composition. The technique methods of operation, planning and exploitation direction must be determined by the workers in the quarry that depended on the data of major element distribution. In the quarry, the raw materials are daily extracted in small amounts for production purposes. In case there is a deviation in raw materials quality, it must modify the chemical composition. 
Table 5. Results of the reserve estimation by the triangle method

\begin{tabular}{|c|c|c|c|c|c|c|c|c|c|c|}
\hline $\begin{array}{l}\text { Tr. } \\
\text { No. }\end{array}$ & $\begin{array}{c}\text { Wells } \\
\text { No. }\end{array}$ & $\begin{array}{l}\text { Th. } \\
\text { (m) }\end{array}$ & $\begin{array}{c}\text { Angle } \\
\text { (degree) }\end{array}$ & $\begin{array}{l}\text { C.F } \\
(\mathrm{m})\end{array}$ & $\begin{array}{c}\text { C.T } \\
(\mathrm{Th} \times \mathrm{C} . \mathrm{F}) \\
(\mathrm{m}) \\
\end{array}$ & $\begin{array}{l}\text { Av. } \\
\text { C.T. } \\
\text { (m) }\end{array}$ & $\begin{array}{c}\text { long of } \\
\text { the line } \\
\text { (m) }\end{array}$ & $\underset{\left(\mathbf{m}^{2}\right)}{\mathbf{A}}$ & $\begin{array}{c}\text { Av. } \\
\text { B.D. } \\
\left(\mathrm{gm} / \mathrm{cm}^{3}\right)\end{array}$ & $\begin{array}{c}\text { Reserve } \\
\text { (ton) }\end{array}$ \\
\hline \multirow{3}{*}{1} & $\mathrm{X} 1$ & 9 & 79 & 1.32 & 11.85 & \multirow{3}{*}{8.85} & 1016 & \multirow{3}{*}{690572} & \multirow{3}{*}{1.735} & \multirow{3}{*}{10601892} \\
\hline & $\mathrm{X} 2$ & 8.7 & 40 & 0.67 & 5.80 & & 1385 & & & \\
\hline & $\mathrm{Y} 1$ & 8.75 & 61 & 1.02 & 8.90 & & 1553 & & & \\
\hline \multirow{3}{*}{2} & $\mathrm{X} 2$ & 8.7 & 45 & 0.73 & 6.38 & \multirow{3}{*}{8.56} & 1011 & \multirow{3}{*}{551466} & \multirow{3}{*}{1.735} & \multirow{3}{*}{8187500} \\
\hline & $\mathrm{Y} 1$ & 8.75 & 40 & 0.67 & 5.83 & & 1095 & & & \\
\hline & $\mathrm{Y} 2$ & 8.5 & 95 & 1.58 & 13.46 & & 1553 & & & \\
\hline \multirow{3}{*}{3} & $\mathrm{X} 2$ & 8.7 & 95 & 1.58 & 13.78 & \multirow{3}{*}{8.61} & 1011 & \multirow{3}{*}{564620} & \multirow{3}{*}{1.735} & \multirow{3}{*}{8430137} \\
\hline & $\mathrm{X} 3$ & 8.5 & 40 & 0.67 & 5.67 & & 1121 & & & \\
\hline & $\mathrm{Y} 2$ & 8.5 & 45 & 0.75 & 6.38 & & 1572 & & & \\
\hline \multirow{3}{*}{4} & $\mathrm{X} 3$ & 8.5 & 42 & 0.70 & 5.95 & \multirow{3}{*}{8.45} & 993 & \multirow{3}{*}{526755} & \multirow{3}{*}{1.735} & \multirow{3}{*}{7718054} \\
\hline & $\mathrm{Y} 2$ & 8.5 & 39 & 0.65 & 5.53 & & 1074 & & & \\
\hline & $\mathrm{Y} 3$ & 8.4 & 99 & 1.65 & 13.86 & & 1572 & & & \\
\hline \multirow{3}{*}{5} & $\mathrm{Y} 1$ & 8.75 & 57 & 0.95 & 8.31 & \multirow{3}{*}{8.70} & 592 & \multirow{3}{*}{272319} & \multirow{3}{*}{1.735} & \multirow{3}{*}{4112488} \\
\hline & $\mathrm{Y} 2$ & 8.5 & 33 & 0.55 & 4.68 & & 920 & & & \\
\hline & $\mathrm{Z1}$ & 8.75 & 90 & 1.50 & 13.13 & & 1095 & & & \\
\hline \multirow{3}{*}{6} & $\mathrm{Z1}$ & 8.75 & 55 & 0.92 & 8.02 & \multirow{3}{*}{8.25} & 770 & \multirow{3}{*}{260075} & \multirow{3}{*}{1.735} & \multirow{3}{*}{3723275} \\
\hline & $\mathrm{Z} 2$ & 7.75 & 78 & 1.30 & 10.08 & & 691 & & & \\
\hline & Y2 & 8.5 & 47 & 0.78 & 6.66 & & 920 & & & \\
\hline \multirow{3}{*}{7} & Y2 & 8.5 & 95 & 1.58 & 13.46 & & 1076 & & & \\
\hline & Y3 & 8.4 & 31 & 0.52 & 4.34 & 8.26 & 691 & 370193 & 1.735 & 5303846 \\
\hline & $\mathrm{Z} 2$ & 7.75 & 54 & 0.90 & 6.98 & & 1331 & & & \\
\hline & $\mathrm{Y} 3$ & 8.4 & 49 & 0.82 & 6.86 & & 808 & & & \\
\hline 8 & $\mathrm{Z2}$ & 7.75 & 37 & 0.62 & 4.78 & 7.95 & 1001 & 403350 & 1.735 & 5565646 \\
\hline & $\mathrm{Z3}$ & 7.8 & 94 & 1.57 & 12.22 & & 1331 & & & \\
\hline & & & & & & & Total & 3639350 & 1.735 & 53642838 \\
\hline
\end{tabular}

Th: Thickness of marl layer; Tr. No.: triangle number; C.F: Correction Factor, C.T: Correction Thickness, B.D: Bulk density $\left(\mathrm{g} / \mathrm{cm}^{3}\right)$, A: Area $\left(\mathrm{m}^{2}\right)$

Triangle method gives an accurate perception of the distribution of the major oxide in the quarry within relatively small areas. It can be easily corrected. The concentration of major oxides in each triangle was calculated by equation (Moon et al, 2006) as below:

Avaregegrade $=\frac{G 1 T 1+G 2 T 2+G 3 T 3}{\Sigma T}$

Where: $\mathrm{G}=$ Grade or concentration of oxides, $\mathrm{T}=$ Length of the core sample

For example, when the equation applied to find out the concentrations of $\mathrm{CaO}$ in triangle 1, which the wells (X1, X2, and Y1) are in its peak the result is $37.12 \%$. 
Avarege grade $=\frac{(36.53 * 9)+(37.52 * 8.7)+(37.34 * 8.75)}{\sum 26.45}=37.12 \%$

Other oxides concentration results can be calculated in the same way in every triangle shown in Table 8.

Table 8. Chemical results $(\%)$ of marl later in each triangle blocks

\begin{tabular}{|c|c|c|c|c|c|c|c|c|c|}
\hline \multirow{2}{*}{ Tr. No. } & \multirow{2}{*}{$\begin{array}{l}\text { BH } \\
\text { No. }\end{array}$} & \multirow{2}{*}{$\begin{array}{l}\text { Th. } \\
\text { (m) }\end{array}$} & \multirow{2}{*}{$\begin{array}{c}\text { Reserve } \\
\text { (ton) }\end{array}$} & $\mathrm{CaO}$ & MgO & $\mathrm{SO}_{3}$ & $\mathrm{SiO}_{2}$ & $\mathrm{Fe}_{2} \mathrm{O}_{3}$ & $\mathrm{Al}_{2} \mathbf{O}_{3}$ \\
\hline & & & & \multicolumn{6}{|c|}{ 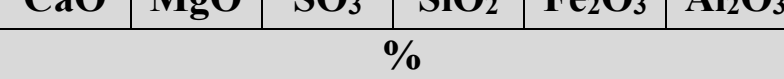 } \\
\hline \multirow{3}{*}{1} & $\mathrm{X} 1$ & 9 & \multirow{3}{*}{9854990} & \multirow{3}{*}{37.12} & \multirow{3}{*}{1.946} & \multirow{3}{*}{0.323} & \multirow{3}{*}{19.01} & \multirow{3}{*}{2.76} & \multirow{3}{*}{4.63} \\
\hline & $\mathrm{X} 2$ & 8.7 & & & & & & & \\
\hline & Y1 & 8.75 & & & & & & & \\
\hline \multirow{3}{*}{2} & $\mathrm{X} 2$ & 8.7 & \multirow{3}{*}{7465801} & \multirow{3}{*}{37.76} & \multirow{3}{*}{1.836} & \multirow{3}{*}{0.458} & \multirow{3}{*}{18.31} & \multirow{3}{*}{2.81} & \multirow{3}{*}{4.14} \\
\hline & Y1 & 8.75 & & & & & & & \\
\hline & Y2 & 8.5 & & & & & & & \\
\hline \multirow{3}{*}{3} & $\mathrm{X} 2$ & 8.7 & \multirow{3}{*}{8560543} & \multirow{3}{*}{37.21} & \multirow{3}{*}{1.953} & \multirow{3}{*}{0.455} & \multirow{3}{*}{18.41} & \multirow{3}{*}{2.73} & \multirow{3}{*}{4.00} \\
\hline & $\mathrm{X} 3$ & 8.5 & & & & & & & \\
\hline & Y2 & 8.5 & & & & & & & \\
\hline \multirow{3}{*}{4} & X3 & 8.5 & \multirow{3}{*}{7775425} & & & & & & \\
\hline & Y2 & 8.5 & & 38.04 & 2.099 & 0.343 & 17.83 & 2.79 & 4.20 \\
\hline & Y3 & 8.4 & & & & & & & \\
\hline & Y1 & 8.75 & & & & & & & \\
\hline 5 & Y2 & 8.5 & 3870101 & 37.73 & 1.873 & 0.421 & 18.25 & 2.82 & 4.33 \\
\hline & $\mathrm{Z1}$ & 8.75 & & & & & & & \\
\hline & $\mathrm{Z1}$ & 8.75 & & & & & & & \\
\hline 6 & $\mathrm{Z2}$ & 7.75 & 38790263 & 38.46 & 1.870 & 0.521 & 16.86 & 2.79 & 3.36 \\
\hline & Y2 & 8.5 & & & & & & & \\
\hline & $\mathrm{Y} 2$ & 8.5 & & & & & & & \\
\hline 7 & Y3 & 8.4 & 5747039 & 39.35 & 2.041 & 0.478 & 16.41 & 2.78 & 3.42 \\
\hline & $\mathrm{Z2}$ & 7.75 & & & & & & & \\
\hline & Y3 & 8.4 & & & & & & & \\
\hline 8 & $\mathrm{Z2}$ & 7.75 & 5434792 & 39.13 & 1.977 & 0.316 & 16.25 & 2.85 & 3.90 \\
\hline & Z3 & 7.8 & & & & & & & \\
\hline
\end{tabular}

\section{Economic Evaluation}

To evaluate the reserve of the industry layer (marl), Kreiter (1968) stated a statistical quantitative method from a 10-point scale by using five parameters (Table 6). These parameters include size, grade, productivity, mining condition and economic conditions of the locality. Each was also roughly divided into three categories. 
Table 6. Statistical quantitative evaluation method for the deposit (after Kreiter 1968)

\begin{tabular}{|l|c|c|c|}
\hline \multirow{2}{*}{\multicolumn{1}{|c|}{ Parameters }} & \multicolumn{3}{c|}{ Valuation points } \\
\cline { 2 - 4 } & 2 point & 1 point & 0 point \\
\hline Scale of deposit & Large & Medium* & Small \\
\hline Grade & High & Medium* & Low \\
\hline Productivity & High* & Medium & Low \\
\hline Mining condition & Very favorable* & Usual & Unfavorable \\
\hline Economic condition & Very favorable* & Usual & Unfavorable \\
\hline
\end{tabular}

*marl layer of study area valuation

The scale of the marl reserve is medium (Table 6) and grade is also considered medium. The marl layer needs to be corrected for $\mathrm{CaO}$, but other components are fit for the Portland cement industry. Production of marl is high ( 2 points) as a result of easy extraction by using an excavator due to its friable properties. The morphology of the study area, which considered flat to semi-flat area, is encouraged for mining work with a condition very favorable that mean to have 2 points in (Table 6). In addition to accessibility for the worksite and road transport accessible and easy construction. The exposure to the surface and accessible with a low stripping ratio in addition to quarry without explosives leads to facilitate the mining and economic conditions were very favorable (2 points). Depending on Kreiter (1968), the marl reserve recorded eight points in statistical quantitative method (Table 6). Five categories for evaluating the reserve was suggested by Al-Atia (2001) (Table 7).

Table 7. Category of reserve evaluation

\begin{tabular}{|l|c|}
\hline Evaluation of deposit & Points \\
\hline Very valuable deposit & $9-10$ \\
\hline Deposits of greater economic importance & $7-8$ \\
\hline Ordinary workable deposit & $5-6$ \\
\hline Doubt workable deposit & $3-4$ \\
\hline Unworkable deposit & $<3$ \\
\hline
\end{tabular}

The marl layer as a reserve in the study area is considered as a deposit of greater economic importance category (Table 7) as it has 8 points in the statistical quantitative method (Table 6).

\section{CONCLUSIONS}

1. The quantity of marl reserve was estimated to be 53 million tons as qualified as raw materials for the cement industry is considered as a medium reserve. However, this quantity is enough for establishing a new cement plant in the Al-Najaf governorate. The 
marl reserve was computed according to the British System and C1 in the Russian System.

2. This new raw material (marl) is a good alternative to clay that provides silica, alumina and ferrite, where limestone is a source of lime.

3. In the case of designing a new plant with a production capacity of 1.5 million tons annually, the raw materials should be calculated based on the conversion factor. This factor is kiln feed to clinker ratio which used to calculate the amount of raw materials. This factor is ranging from 1.65 to 1.75 .

4. By assuming the marl quantity is $78 \%$ as a raw material for the kiln feed, hence, the amount of marl consumed annually will be 1.989 million tons resulted from 2.55 multiply by 0.78 . The marl reserve will be adequate for 27 next years as a result from 53 divided by 1.898 .

5. The hardness of the marl layer is friable at the $0.5 \mathrm{~m}$ depth to the end of the layer while the upper part to the surface is of low tough indicating that the industrial layer can be excavated by hydraulic excavators without using explosive materials.

\section{ACKNOWLEDGEMENTS}

The authors are grateful to the staff of Kufa Cement Company for its assistance in the field work and drilling wells, and thanks are due to the Building Research Center for making their labs available for us to conduct some experiments and the process of burning for the clinker formation. The authors are very grateful to the secretary of Journal Mr. Samir R. Hijab. and head of the technical editors Dr. Heba S. Al-Mimar for their great efforts and valuable comments.

\section{REFERENCES}

Al-Atia, M. J., 2001. Evaluation of Mineral Deposits, Practices in Economic Geology. GEOSURV, Iraq. 157P. Al-Bassam, K. S., 1993. Minerals Prospecting and Exploration, work procedures No.14. Report No. 2133. GEOSURV, Iraq. (In Arabic).

Al-Dabbas, M., Awadh, S. M., and Zaid, A., 2013. Mineralogy, geochemistry, and reserve estimation of the Euphrates limestone for Portland cement industry at Al-Najaf area, South Iraq. Arabian Journal Geoscience, 6:491-503. DOI 10.1007/s12517-011-0370-z.

Al-Dabbas, M., Awadh, S. M., and Zaid, A., 2014: Facies analysis and geochemistry of the Euphrates Formation in Central Iraq. Arabian Journal Geoscience, 7:1799-1810. DOI 10.1007/s12517-013-0932-3.

Awad, A. M. and Awadh, S. M., 2020. Reserve estimation of Late Miocene Injana claystone beds for Portland cement and brick industry, middle of Iraq. Iraqi Geological journal, 53 (1D): 1-16.

Awadh, S. M., Abood, Z. S., and Eisa, M. J., 2013. Chemical and physical control processes on the development of caves in the Injana Formation, Central Iraq. Arabian Journal Geoscience, 6:3765-3772. DOI $10.1007 / \mathrm{s} 12517-012-0637-\mathrm{z}$.

Awadh, S. M., and Al-Ankaz, Z. S., 2016. Geochemistry and petrology of Late Miocene-Pleistocene Dibdibba sandstone Formation in south and central Iraq: implications for provenance and depositional setting. Arabian Journal Geoscience, 9:526 
Brown, E. T., 1981. Rock Characterization, Testing and Monitoring - ISRM Suggested Methods. Pergamon, Oxford, 171-183 pp.

Buday, T., 1980. The Regional Geology of Iraq. Stratigraphy and Paleogeography. Publ. of GEOSURV, Baghdad, 1: $445 \mathrm{P}$.

Buday, T., and Jassim, S. Z., 1987. The Regional Geology of Iraq, Tectonism, Magmatism and Metamorphism. Publ. of GEOSURV, Baghdad, 2: 352P.

Chatterjee, A. K., 1979. Phase composition, microstructure, quality and burning of portland cement a review of phenomenological interrelation- Part 2. World Cement Technology, 10: (5): 165-172.

Ertek, N., and Öner, F., 2008. Mineralogy, geochemistry of altered tuff from Cappadocia (Central Anatolia) and its use as potential raw material for the manufacturing of white cement. Elsevier Ltd. Applied Clay Science, $42: 300-309$.

Henley, S., 2004. Russian mineral. Mining Journal, London, 81-21.

Hoek, E., Marinos, P. and Benissi, M., 1998. Applicability of the geological strength index (GSI) classification for very weak and sheared rock masses. The case of the Athens Schist Formation. Bull. Eng. Geol. Env. Springer-Verlag, 57: 151-160.

Jassim, S. Z. and Goff, J. C., 2006. Geology of Iraq. Published by Dolin, Prague and Moravian Museum. Czech Republic. 341P.

Kreiter, V. M., 1968. Geological prospecting and exploration. Mir Publishers, Moscow, Russia. 385P.

Lipton, I. T., 2001. Measurement of Bulk Density for Resource Estimation in "Mineral Resource and Ore Reserve Estimation, 1st ed. The Australian Institute of Mining and Metallurgy (IMM) Melbourne". 57-65 pp.

Moon, C. J., Whateley, M. K. G. and Evans, A. M., 2006. Introduction to Mineral Exploration. $2^{\text {nd }}$ ed., Blackwell Publishing. USA. 499P.

Price, D. G., 2009. Engineering Geology Principles and Practice. $1^{\text {st }}$ ed., Springer-Verlag Berlin Heidelberg. 460P. Sissakian, V. K., 2000. Geological Map of Iraq, scale 1:1000000, $3^{\text {rd }}$ edition, GEOSURV, Baghdad, Iraq.

Wellmer, F. W., Dalheimer and Wagner, M., 2008. Economic Evaluations in Exploration. $2^{\text {nd }}$ ed., Springer Berlin, Heidelberg, New York, 263P. 